\title{
PREVALENCE OF SECESSION STYLE DÉCOR ELEMENTS IN INTERIORS OF LITHUANIAN MANOR RESIDENCES
}

\begin{abstract}
Summary. This article's aim is to demonstrate the secession décor's implementation in manor house interiors throughout Lithuania. Secession style is very different from historicist styles and was popular for a short period of time, which is why it did not gain popularity in all Europe. This organic style is usually closely related to urban culture, but, in the past, the main cultural life in Lithuania developed in manors. Nevertheless, secession style décor and interior design was not as popular in manor houses as in city buildings. Because of that, all details and elements of secession style are very important for Lithuania's cultural heritage. Several examples from Renavas, Rokiškis, Gelgaudiškis, Paežeriai, Burbiškis, and Šešuolèliai manor residences’ interiors show how secession style was created in Lithuanian countryside. The new style brought changes, such as asymmetric facades, new floor plans and perception of private space, and new interior décor. Iconographic material of secession style décor elements in interiors of Lithuania is rare, but, by combining it with historical, art, and polychromic research, it is possible to describe the details of secession style in the interiors of Lithuanian manor houses.
\end{abstract}

Keywords: secession interiors, Lithuanian manors interiors, secession in manor residences.

\section{INTRODUCTION}

Interiors of Lithuanian manor houses are not a popular field of research. One of the reasons for that is a lack of iconographic and historical material. However, during these decades of Independence, interest in and concern for cultural and architectural heritage has increased. Some manor houses are restored on the basis of polychrome, architectural, historical, and art research. Such research makes it possible to identify changes in interior decorations throughout the years, to examine the details of style, and to restore former interiors. We know the most about walls, ceiling decor, building construction. Unfortunately, interior photography of secession in the late 19th-early 20th centuries of Lithuania is rare, so knowledge of furniture and other interior details is fragmented.

In Lithuania, secession style was popular at the same time as in other parts of Europe: from around 1900 to the First World War. ${ }^{1}$ Given such a short period of time, it is obvious that there is not much information remaining about secession in Lithuanian manor houses. However, during the period of secession style, significant changes took place both in Lithuanian and in European societies. Despite the fact that Lithuania was a part of the Russian Empire, new cultural winds had their influence on Lithuanian noblemen. The changing view towards individuals and their private space influenced principles of building planning and decoration directly. The noblemen tried to transfer latest cultural innovations and the spirit of diversity to their own living environments. Despite the fact of this short time of dissemination, secession was a very modern, organic style, which was quite rare in mansion residences. Elements of secession style found in the interiors of Lithuanian manor houses are useful for décor analysis, as it would purposely reveal the characteristic features of Lithuania. Therefore, the examined period of secession style allows for a better understanding of the changing architectural and cultural aspects of society.

There is not much research on secession in Lithuanian manor houses. Nijolè Lukšionytė-Tolvaišiene was one of the first authors to research secession in Lithuania. A lot of important information was published in Lietuvos architektūros istorija 
(History of Lithuanian architecture). ${ }^{2}$ The main differences between secession and historicist styles are explained in the latter book. Also, new trends of the late 19th-early 20th centuries are described and main concepts all around Lithuania explained there. A chapter on historicist manor houses was written by Vytautas Levandauskas. ${ }^{3}$ He described how manor houses were built in the historicist era and how secession made an impact on them later on. However, Lukšionytė-Tolvaišienës researches about secession in Lithuania concentrate mostly on Vilnius and Kaunas rather than on the interior décor of manor houses. ${ }^{4}$ Dalia Klajumienè published a huge study Vilniaus gyvenamuju namu interjeru dekoro elementai nuo klasicizmo iki moderno (Interior Décor Elements of Vilnius Residential Houses: from Classicism to Modern). ${ }^{5}$ This study showed how interior décor in Vilnius has changed throughout decades, described differences between styles, and, to quote the author, "set a valuable base for further research and discussions". ${ }^{6}$ Laimutè Cieškaitè-Brèdikienè published a textbook of design that includes secession style, too. ${ }^{7}$

Iconographic documents depicting authentic interiors from that specific time are one of the best sources of information on interior décor. Unfortunately, not many can be found. Documents of historical, art, and polychromic research are another source of information that can be used. Usually these documents are from the end of the 20th or beginning of the 21st century. Historical and art research of Burbiškis manor started in 1982 and is still updated from time to time. ${ }^{8}$ Paežeriai historical research was also carried out in the same year. ${ }^{9}$ Polychromic research of the interior of Renavas manor residence was completed in 1986 and supplemented with an additional document about the main building in $1988 .{ }^{10}$ Rokiškis palace polychromic interior research was carried out in $1991 .^{11}$ Manor of Šešuolèliai main dossier of documents was compiled in 2002-2004. ${ }^{12}$ Gelgaudiškis floor scheme for early colouring of premises and indoor painting projects was made in 2009 and polychromic research in $2012 .^{13}$

There are many books about manors in Lithuania, however, the published information is usually based on the same archival data. Moreover, the Department of Cultural Heritage of Lithuania has an important and useful website. ${ }^{14}$ It provides information about historical, architectural, artistic, and various other heritage objects.

According to Klajumienè, even back in the late 19th and early 20th century, interior design was often described as not valuable or not worthy of preservation. ${ }^{15}$ This view could have been based on the opinion that the styles in question were not old enough to preserve. Therefore, interior décor of importance to Lithuanian culture and architectural heritage could have been lost and, quite possibly, is. There is also a widespread opinion that secession was characteristic to urban culture, despite the fact that manor houses were the centre of cultural life in Lithuania for a long time, including the period when Lithuania was in the Russian Empire. As a result, there is not enough research on secession style interior décor in Lithuanian manor houses.

This article's aim is to analyse the elements of secession style in interior décor of Lithuanian manor residences. Its tasks are to describe the changes in building architecture and floor plan schemes in Lithuanian manor houses and to analyse secession style interior décor in Lithuanian manor residences by using cases of Renavas, Rokiškis, Gelgaudiškis, Paežeriai, Burbiškis, and Šešuolèliai manors. This study used the descriptive method to discuss historical details of the secession. Case studies were used to analyse selected manor palaces as separate objects. The comparative method facilitates understanding of similarities and differences of the secession style between Lithuanian and foreign residences. Stylistic analysis is used to emphasise the regularities of art styles reflected in the objects. Because there is not much information about the interiors, reconstructive method helps restore the décor and the entirety of interiors from fragmentary information in a consistent and systematic manner.

Based on several manor houses in Lithuania, main aspects of secession décor will be highlighted by using information and knowledge gained from photographs, archival documents, previous research, and examples from foreign countries. 


\section{EXPLANATION OF IMPORTANT TERMS}

First of all, it is necessary to explain the terms that may cause confusion. One of the main words used in this article is "manor", which, according to Dailes žodynas (The Art Dictionary), is a large landowner's homestead with residential, farm, and industrial buildings. The centre of all manor buildings, composition is a palace or a simpler manor house. ${ }^{16}$ A manor is often compared to the main residential building of a palace, but that is a mistake. A palace or a manor house are just parts of a manor itself. In the Dictionary of Architecture and Construction, "manor house" and "mansion" are used as synonyms. ${ }^{17}$ However, depending on the owner's aspirations and financial capabilities, manors' central houses could look very different. In the English language, "manor house" means an imposing house in a countryside, often the residence of a landowner with considerable acreage. ${ }^{18}$ Also, in French, "chateau" is: 1. A castle or imposing country residence of nobility in old France. 2. Now, any French country estate. ${ }^{19}$ According to Lukšionytė-Tolvaišienè, "manor residence houses were different in size and luxury. Rich and noble families would build representative palaces with huge ceremonial halls." However, Lithuanian noblemen more often chose simpler options: "The small noblemen had simple one-storey mansions. There were also intermediate options between the representative palace and the estates - the villalike buildings." ${ }^{20}$ Likewise, Levandauskas is using the terms palace, residential house, and estate interchangeably. ${ }^{21}$ Words like "palace", "residential house", "residence", "manor house", and other similar terms are used as synonyms in this article. Lithuanian palaces differed greatly in their décor and its combinations. It should be noted that sometimes a countryside manor house would become a part of a town when the village would expand. However, it was common to build initial manor houses in the countryside, away from settlements.

Also, it is necessary to explain the meaning of "secession style". According to Lukšionytè-Tolvaišienè, the beginning of the inspiration for this style can be found in architecture and fine arts of England, Belgium, Austria. ${ }^{22}$ It is interesting that the expression for "secession" was different in different countries. For example, in France it is art nouveau, in Belgium-sezession, in Russia-модерн (modern), in Germany-Jugendstil, and in Poland-secesja. ${ }^{23}$ All these different titles have the same meaning: "To create a new style, to be separated from historical styles and old schemes." ${ }^{24}$ In Europe, this new style was created by using décor details of wildlife, animals, and plants, as well as curved lines and new structures and materials. It has to be admitted that, in Lithuania, the secession was more modest and expressed through cultural and architectural details rather than through the very visual features of décor, as seen in other countries. Titles of "secession", "art nouveau", and "modern" are most often used in Lithuania. In English literature, the more international term "art nouveau" is often used. Although Lithuania was a part of Tsarist Russia, the term "modern" should be avoided so as to not cause misunderstandings. The adjective "modern" is confusing and can lead to mistakes when comparing secessionist and modernist architecture. However, both Lukšionytė-Tolvaišienė and Klajumienè are using "modern" as a synonym for "secession".

Polish speakers made up the majority of Lithuanian noblemen and they were using the term "secession"; that is why this term is used in this article, as well. Moreover, Lukšionytè-Tolvaišienè has said that architecture magazines had arrived to Lithuania from Warsaw and Kraków; fine arts exhibitions and architects were invited to Lithuania from Poland, too. Individual buildings were designed by well-known authors: Cz. Przybilski, S. Witkiewicz, K. Jankowski, F. Lilpop. Secession was called the New Art and this title was used by Vilnius intellectuals, including the architects themselves. ${ }^{25}$ Because of that, it is acceptable to use the common title of the time.

\section{CHANGES IN BUILDING ARCHITECTURE AND FLOOR PLAN SCHEMES}

In European cities, the secession style design was vivid and bright, with soft details all over the façade and inside the building; but it was different in Lithuania. It is interesting that secession in Lithuanian manor residencies was expressed by asymmetry 
and secession itself through a retreat from the usual academic styles. This modern and organic style was expressed by more modest interior décor and also through cultural, architectural, and layout changes. Floor plan changes are one of the main secession style expressions to be described in this chapter. For a better understanding of the floor plans, the cases of Rokiškis, Gelgaudiškis, Paežeriai, and Šešuolèliai manor houses will be examined.

It is worth mentioning that, according to the Baroque epoch etiquette, it was mandatory to organise huge receptions for guests in the main part of a palace in a magnificent salon or main halls. Later, during the period of Romanticism, buildings started to change into more private spaces. The main function of a manor residence changed into being a cosy place for the family to live and spend time together, and receiving guests or organising a ball was only a secondary function. ${ }^{26}$ According to Lukšionytè-Tolvaišienè, this trend could have begun in England. "My house is my castle" is an old and well-known saying. This approach was expressed through reorganisation of former representational spaces into personal ones. It meant much more privacy in personal life, adaptation to family's demands, etc. ${ }^{27}$ A corridor as access from one room to another is standard these days, but back then it was an innovation.

The difference between private and representational spaces is displayed perfectly in the ground floor plan of Šešuolèliai manor residence. To the right of the entrance hall is an enfilade structure connection between rooms, probably remaining from earlier times. On the other hand, there is a narrow corridor to the left of the entrance hall. Another example is Paežeriai manor house. From the floor plan, it is clear that the ground floor was used for representation: it is comprised of halls, salons, and a dining room, whereas the second floor had private rooms for the owners connected by a corridor.

As mentioned previously, the secession brought planning changes to Lithuanian manor houses: places were adapted for comfortability and had more private space. Because of that, it is natural that enfilade connection became uncomfortable and old-fashioned. Besides the new manor houses, there were the old reconstructed ones, too, like the Gelgaudiškis Palace: "The rooms on the South were separated from the ones on the North by corridors going right and left from the central lobby after the 20th century reconstruction.” ${ }^{28}$ The Rokiškis Palace is important for the changes of its hall, too. The main salon became a hall for family gatherings. Having in mind family relations and wanting to spend time together was common in the secession period. So, a huge ball hall was transformed into a cosy space for family and friends' leisure time (Fig. 1). Also, it is necessary to mention the introduction of electricity and central heating. The late 19th-early 20th centuries was a period of major changes for humanity: expansion of the middle class, industrial and economic growth, peoples' desire to be individuals, etc. All of this was reflected in the everyday life.

The Gothic revival and the Arts and Crafts movements were popular in the 19th century, which was the beginning of architectural changes. According to Lukšionytė-Tolvaišienè, William Morris' Red House, built in 1859, is an example of building structure changes. ${ }^{29}$ The resemblance between the Rokiškis Palace and Red House is similar in regards to its building floor plan which is connected around the entrance hall. The same idea was applied to the ball hall reconstruction in Rokiškis. A huge fireplace made the space cosy. The fireplace décor consists of sandstone and wooden cornices. The monumental fireplace is thought to be inspired by the neo-Gothic stylistic ideas from England. This idea is supported by Jonas Rimantas Glemža: "A large two-story hall, reminiscent of the traditional palace, is similar to those in English manor houses. A fireplace and decorative wood panels with shelves on which you can exhibit ceramic or other artwork are the main décor of this interior. The ceiling is made from decorative wood panels." 30

So, to Lithuanian manor residences, the secession brought a new perspective on the floor plan, a new private space perception, and new utilitarian equipment; all of these affected the construction of buildings. 


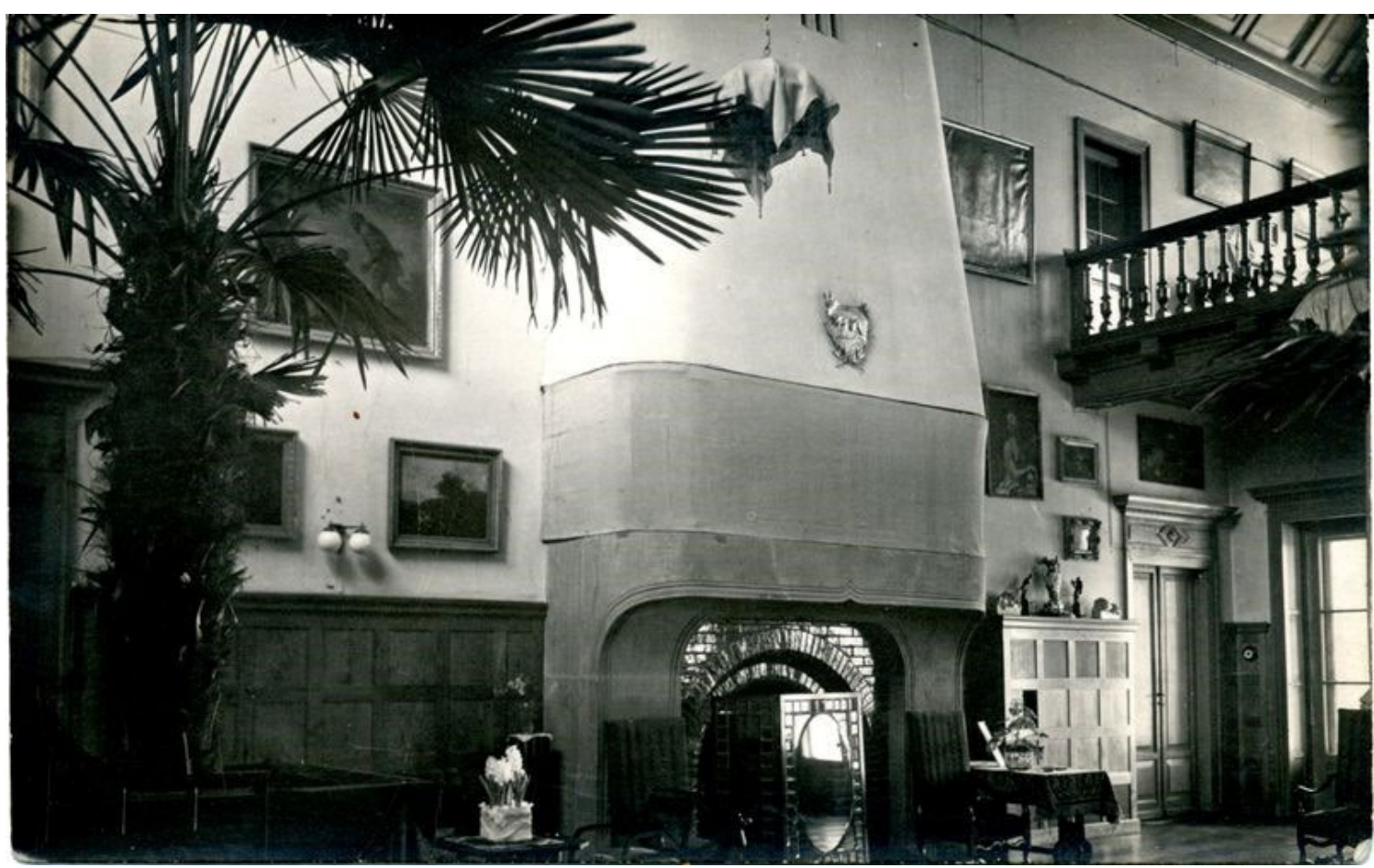

Fig. 1. Interior of Rokiškis manor hall. Early 20th century. Accessed February 12, 2019. https://www.limis.lt/paieska/ perziura/-/exhibit/preview/56384713?s_id=gpA0otQg5DCMWpHC\&s_ind=347むvaluable_type=EKSPONATAS

\section{SECESSION STYLE INTERIOR DÉCOR IN LITHUANIAN MANOR RESIDENCES}

During the secession period in Lithuania, new manor houses were built and the old ones were reconstructed. It is worth mentioning that secession style decor in Lithuanian residences is mostly found in bedrooms or other private rooms and rarely in the entrance halls. In this article, several examples of secession style interior décor from Lithuanian manor houses are mentioned. Different types of buildings, from the more usual Lithuanian manor palaces of Renavas and Gelgaudiškis to the more original historicist-eclecticist Rokiškis Palace, to the smaller residences of Paežeriai and Šešuolèliai and, finally, the totally unusual building complex of Burbiškis, show that the secession was popular in various types of manor houses and various locations in Lithuania. Secession style décor was used in older reconstructed buildings, as well as in the new ones. Although there are more manor houses with secession style interior décor in Lithuania, there is not much information about secession elements in their interior design. These examples show both similarities with the secession in bigger European cities and the local approach. Studying restored authentic interiors such as those in Renavas, Rokiškis, and Gelgaudiškis, or the almost authentic ones such as those in Šešuolèliai or Burbiškis is convenient, because various researches were carried out about them and there is more information available. However, this cannot be said about Paežeriai manor residence. In this case, interior photographs from the early 20 th century were the main research material.

\section{RENAVAS (MAŽEIKIAI DISTRICT)}

The Renavas Palace was built in the period of late classicism. More information remains about décor from this period than the secession one. The current interior decoration is the result of two or three renovations made in the 1880 s and the early 20 th century. ${ }^{31}$ Based on Marija Melžytës memories, the changes to the Renavas manor palace's interior and floor plan were made before 1914. The entrance hall had a higher ceiling than other premises and the walls were painted green up to their middle and covered with oak boiseries with secession elements. ${ }^{32}$

Previous secession style décor was restored based on the 1986 polychromic research by Daujotaite and the 1988 drawings by Tarabildiene. ${ }^{33}$ The 


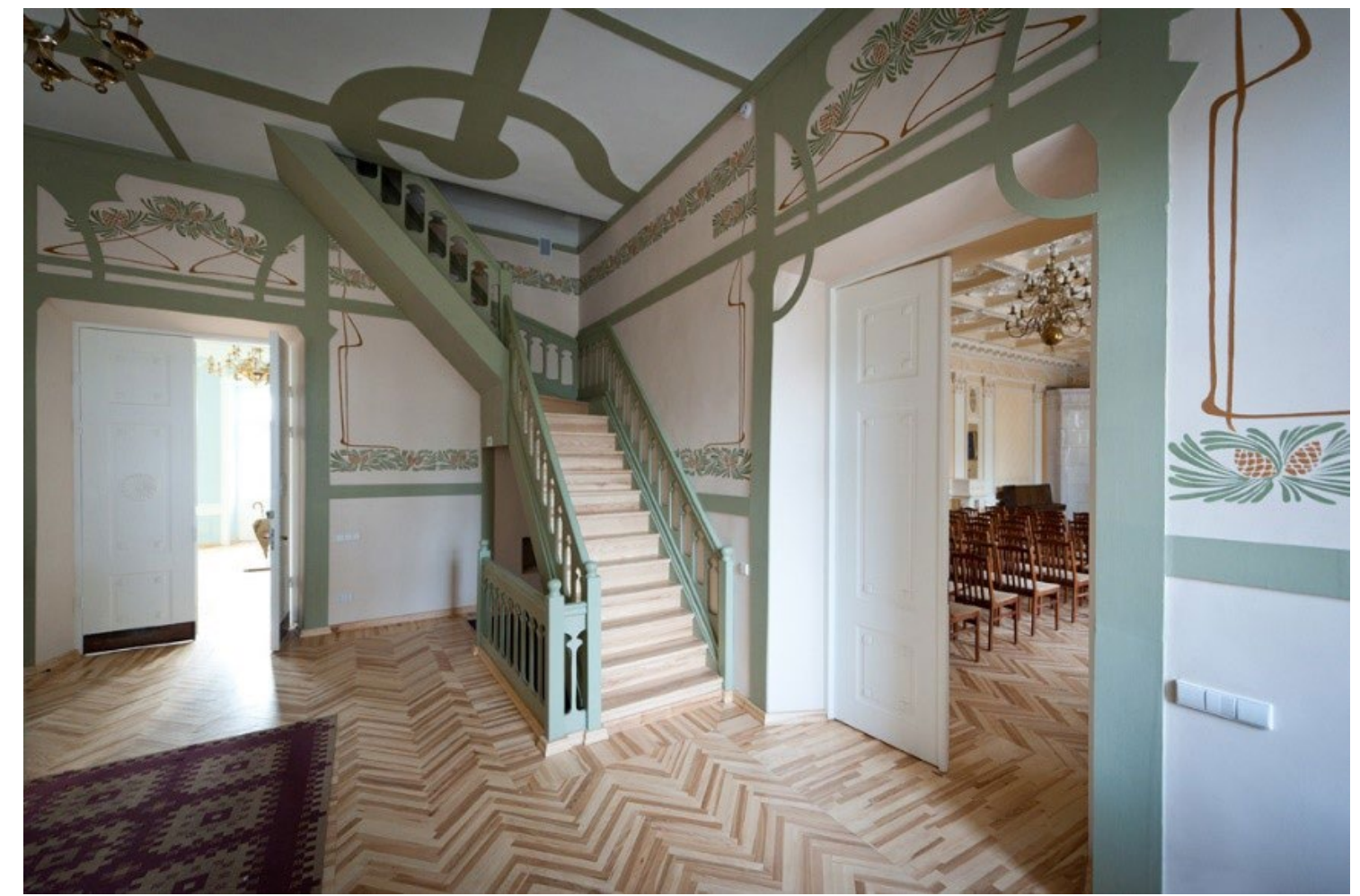

Fig. 2. Interior décor of the Renavas Palace entrance hall. Photography by Leonas Garbačauskas, 2012

entrance hall was decorated with light green lines and pine cone ornaments (Fig. 2). The ceiling was painted with green geometric shapes and lines on a white base. The doors' décor was created in the same style as that of the walls and the ceiling. The wooden décor of overdoors, wall arrangements, and ceiling all merge together. The railings on the stairs are made from natural, oval shaped elements. On the second floor there are doors which reflect the décor shape of the stairs (Fig. 3). It may look as an insignificant detail, but, if compared to the interior doors created by Antoni Gaudí, it would be noticeable that the doors of the Renavas Palace are created in the same manner (Fig. 4). A fireplace decorated in secession style is in the entrance hall as well. According to Lukšionyté-Tolvaišienè, pine spike and cone ornaments are rare in secession style art. ${ }^{34}$

Although there are few good reviews of the secession style period, in the same book LukšionytèTolvaišienè wrote: "However, the late interior décor is of massive nature and overflows with pompous details-it is typical of the urban bourgeois environment. Since the end of the 19th century, beautiful interiors have been identified with luxury. The elegance of the early and late 19th century

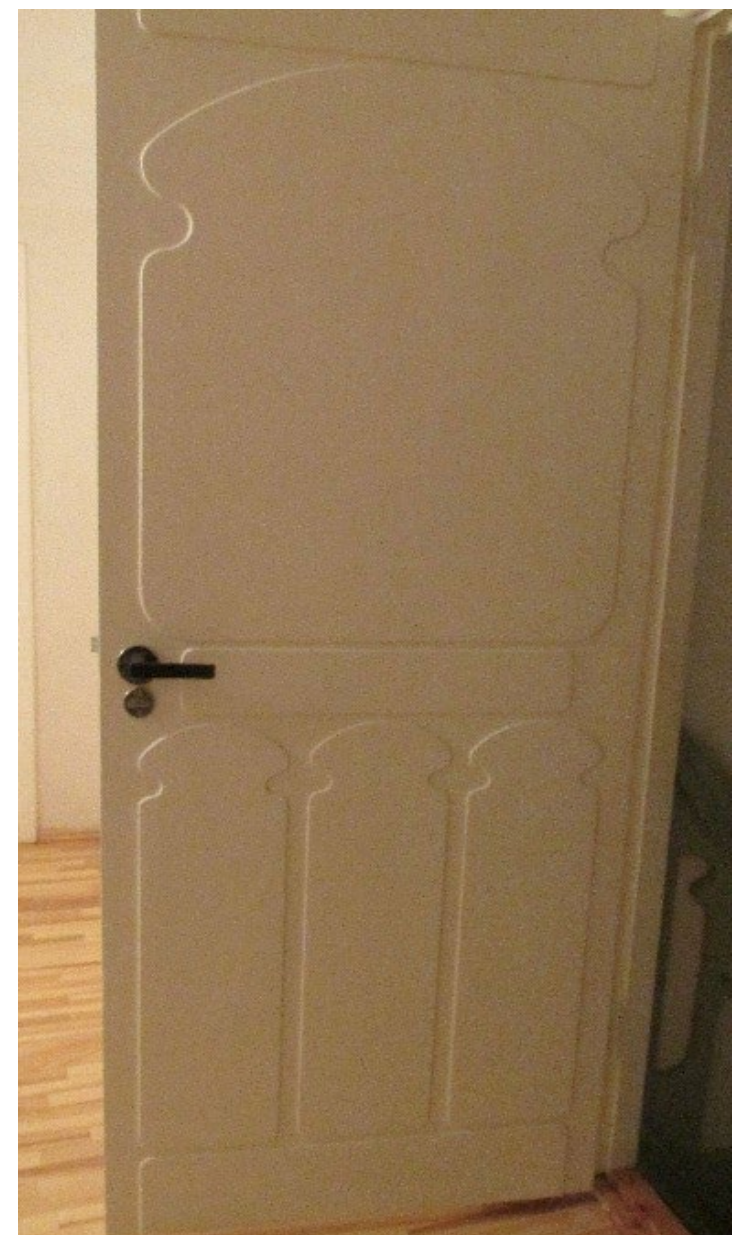

Fig. 3. Door on the second floor of the Renavas Palace. Photography by Rimante Stankünaite, 2019 


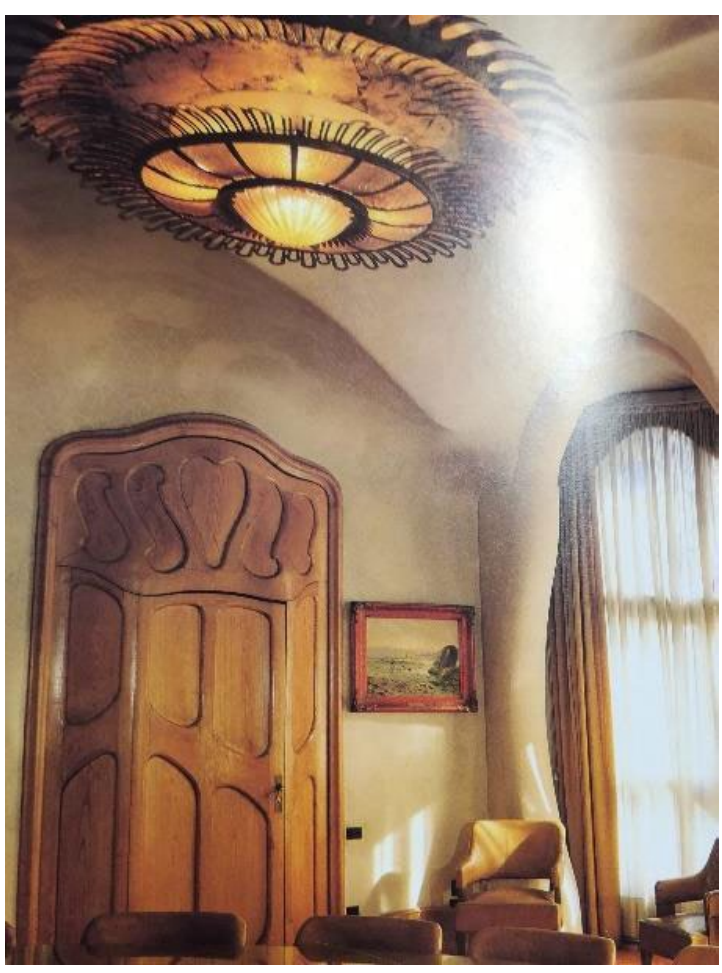

Fig. 4. Interior of Antoni Gaudi’s Casa Batlló, 1904-1906. In: Reiner Zerbst, Antoni Gaudi (Köln: Taschen, 1985), 163

was forgotten." ${ }^{35}$ This quotation makes it clear that organic secession décor was underestimated. Also, Lukšionyte-Tolvaišienè claims that secession style décor in the entrance hall was the earl's whim to keep up with the new style, popular in the early 20th century. ${ }^{36}$ Glemža does not highlight any original secession style décor either. ${ }^{37}$
Another room with secession style interior is the owner's office. The secession period walls are decorated in light blue; the playfully painted lines and plant ornaments with yellow blossoms were restored based on the Daujotaite’s 1988 polychromic research. ${ }^{38} \mathrm{~A}$ wide frieze is painted around the room (Fig. 5). In comparison with the entrance hall, this interior is much more modest but also reflects the new style.

So, it is worth to do researches and point out that Lithuanian manor houses were redecorated with secession décor. The Renavas Palace entrance hall's interior décor is proper secession aesthetics. Great secession style expression was created with local pine tree ornaments. The office is decorated with simpler plant ornaments.

\section{ROKIŠKIS}

The Rokiškis Palace takes a special place in the Lithuanian context. This building was reconstructed in 1905. The Palace was transformed from classicist architecture into eclecticism. ${ }^{39}$ The project was created by Polish architects Jakowski and Lilpop. ${ }^{40}$ Supposedly because of that, the new secession ideas were well implemented. The most well-known is the Zakopanski style dining room (Fig. 6). This room differs from other Lithuanian manor residences' dining rooms. The room is decorated with wooden

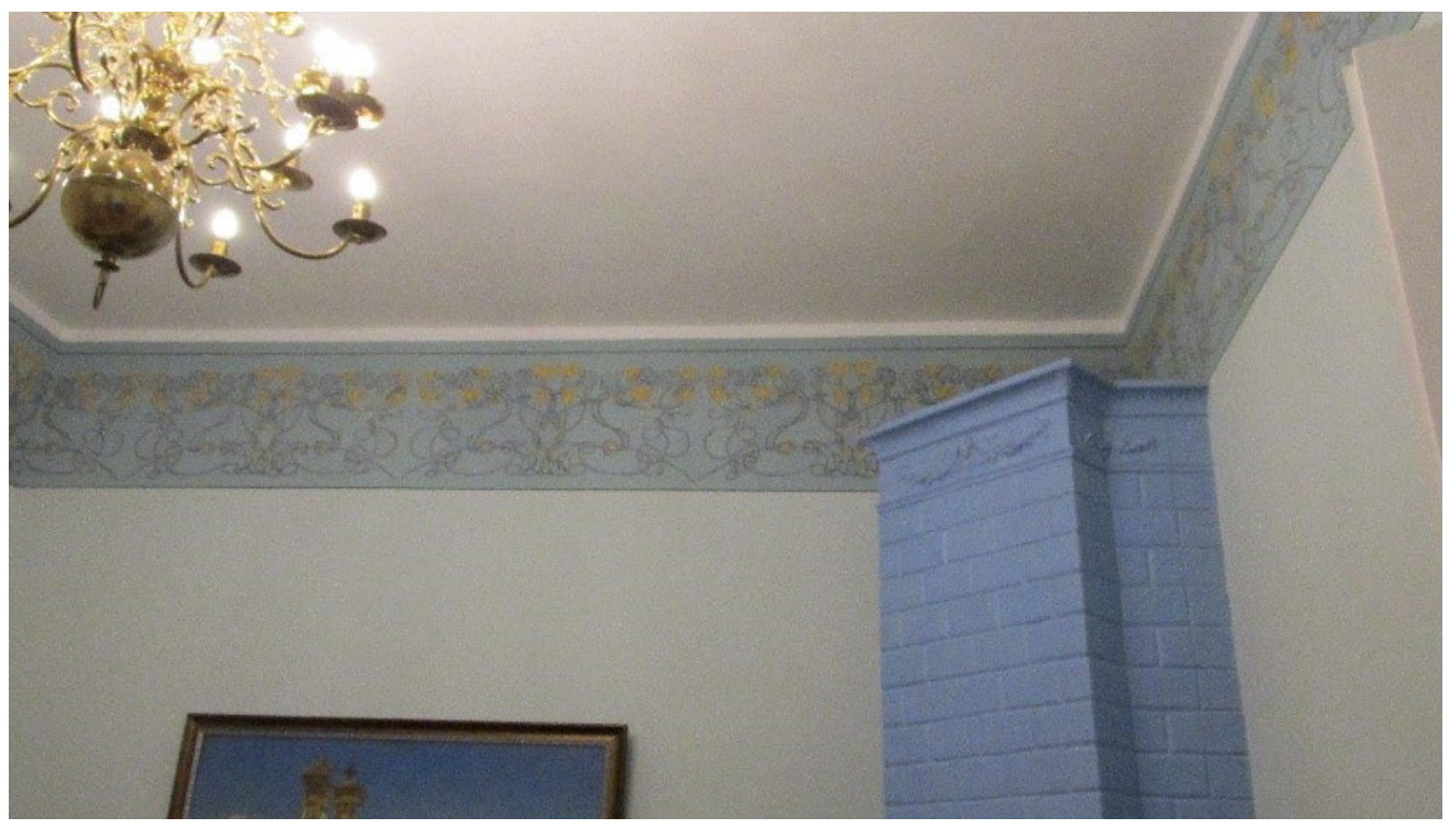

Fig. 5. Office of the Renavas Palace. Photography by Rimantè Stankūnaitè, 2019 


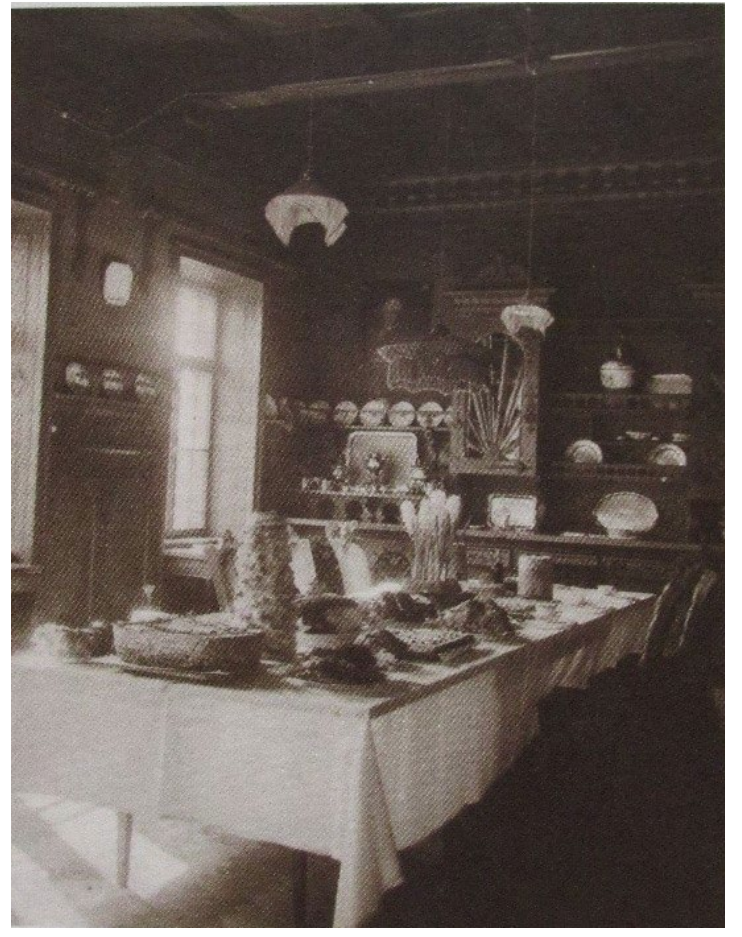

Fig. 6. Zakopanski style dining room in the Rokiškis Palace. In: Danguole Kandrotiene and Vytautas Kandrotas, 153 įdomiausi Lietuvos dvarai (Kaunas: Terra publica, 2011), 108

panels, woodcuts of ethnic ornaments, and ironwork. The sideboards are made from Zakopanski style glass with beam design. All parts of the dining room look like they are connected by the abundant shelves. The fireplace is decorated with green glazed tiles, an often-occuring element in the secession.

\section{GELGAUDIŠKIS (ŠAKIAI DISTRICT)}

The Gelgaudiškis manor palace's interior is phenomenal in the Lithuanian context. Its representative building is authentic with restored interiors. Polychromic studies have shown that the first stage of painting the walls was carried out in 1898-1914. According to Trečiokienè, the building's floor plan and interior had changed during that time. ${ }^{41}$ As mentioned before, the enfiladic floor plan was supplemented with a corridor conection between rooms. Changes were made in the interior design, too, although the entrance and the main hall's interiors are of the historicist style. Despite the fact that Gelgaudiškis manor house has an authentic secession style décor, there is not much information or studies about it. Even in the huge book about the history of Gelgaudiškis, the authors write about the décor from the previous period and not about the secession one. ${ }^{42}$

The Gelgaudiškis Palace's rooms and halls are decorated with secession style moldings, created with ornaments of plants, flowers, and geometric forms. For example, the former owner's room is decorated with Chinese chrysanthemum moldings for the cornices (Fig. 7). The ceiling is decorated with the same flowers and three big circular compositions. The authentic colour of the walls was yellowish and the ceiling was light blue. The floral moldings are recreated in their authentic colours, too-yellowish, light blue, and light green. The overdoors are fitted with similar design and flower motives. According to the polychromic research, "ornamented moldings in the rooms: overdoors, friezes, walls, and plafonds were researched partially." ${ }^{43}$ It is interesting that the doors and the shutters were painted to look like wood. First, a light ocher base was applied and covered with a thin layer of lacquer and then the surface was painted dark brown. By this method, the imitation of wood was created.

Secession style décor is abundant in other rooms, on frieze and ceilings plafond. One interior décor is created by three straight lines starting from a circular motive with three horizontal lines beneath it (Fig. 8). A very similar design can be found in the Eizenštein apartment house at 4 Alberta Street in Riga (Fig. 9). Also, a blossoming tree is inserted in the ceiling corners of this room in the Gelgaudiškis Palace. The overdoor is, very symbolically, decorated with moldings depicting three tree trunks and roots. In the room's corner, there is a fireplace with secession style décor, too. There are similarities between this fireplace and the fireplaces in another Eizenštein apartment house at 13 Alberta Street. Of course, the secession in Riga was much more prevalent, but similar elements were used in the Gelgaudiškis Palace's interior, as well.

In the late 19th century, people began to think how to improve everyday life and better their living standards. Water supply, sewerage, central heating, and electricity systems were installed. Ceramic, mettlach, and other types of tiles started to be used for the 


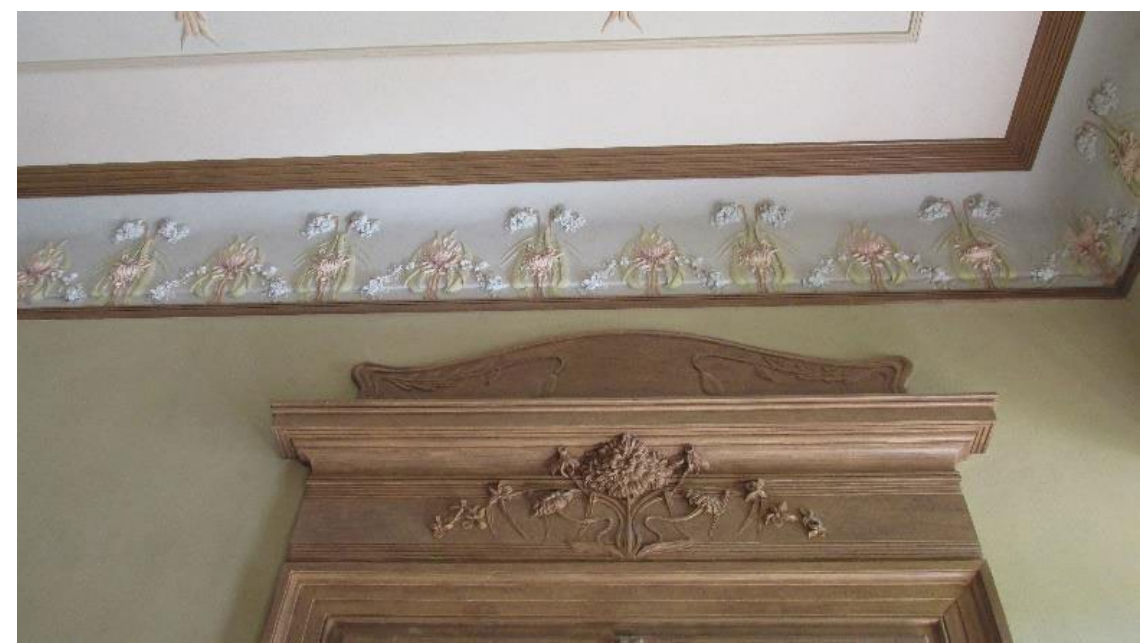

Fig. 7. Room decorated with Chinese chrysanthemum moldings in the Gelgaudiškis Palace. Photography by Rimantè Stankūnaitè, 2018

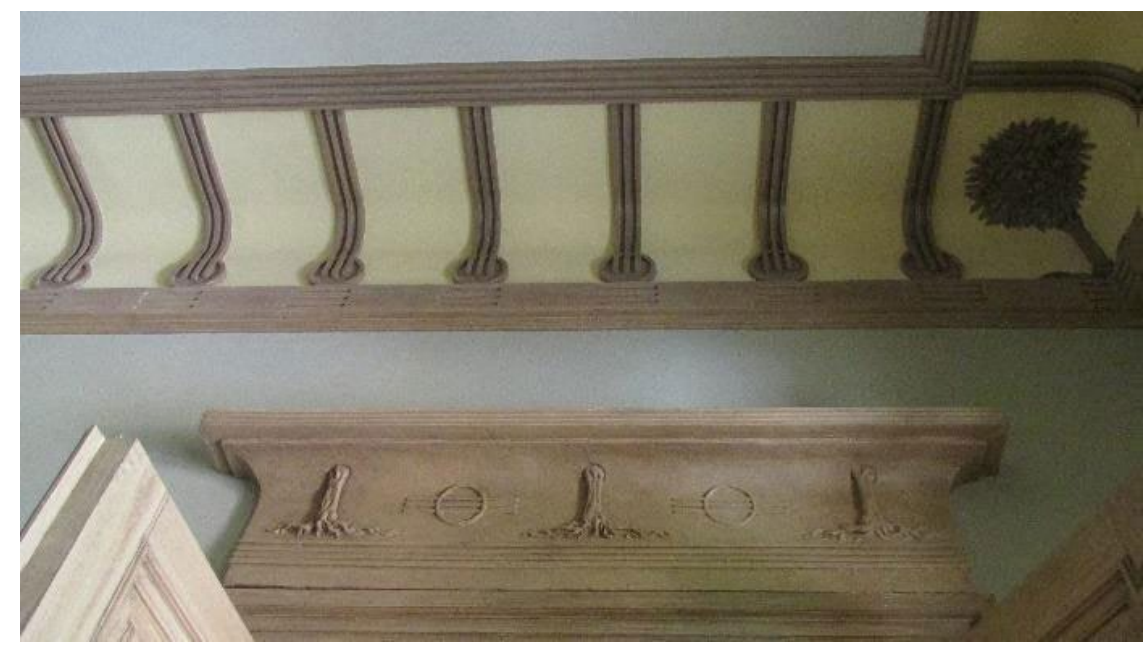

Fig. 8. Gelgaudiškis manor's moldings. Photography by Rimantè Stankūnaitè, 2017

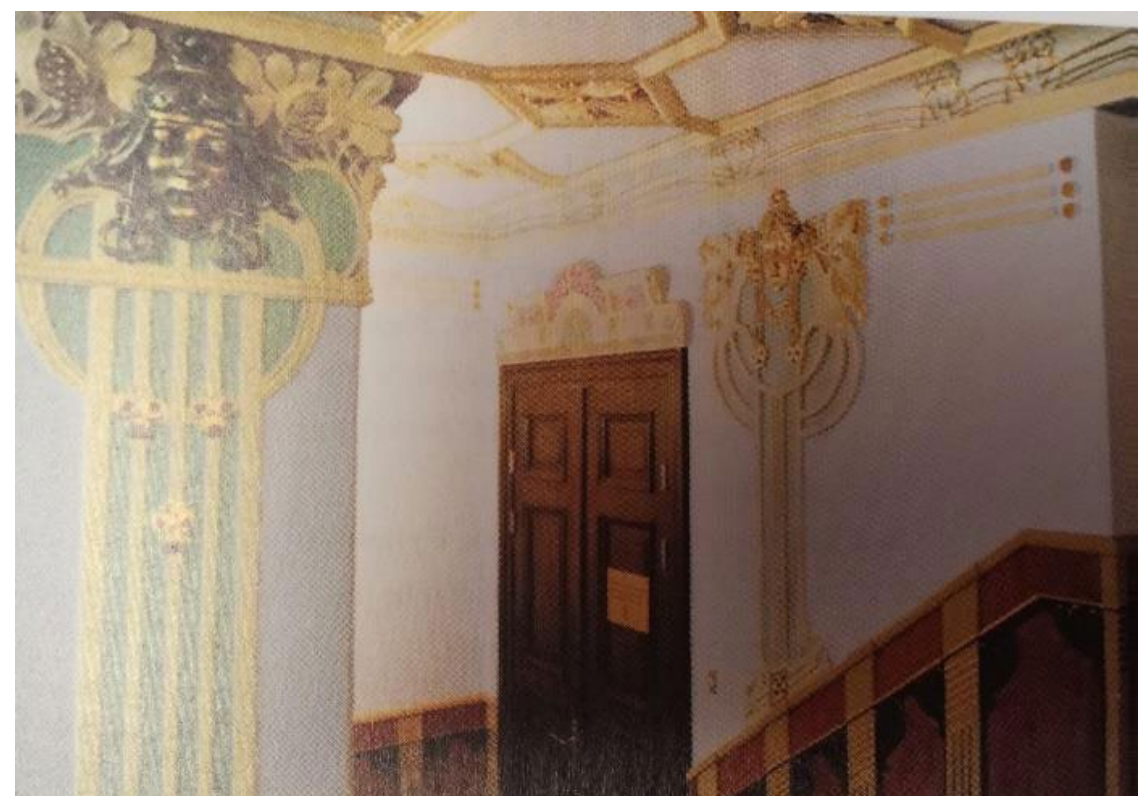

Fig. 9. Eizenštein apartment house at 4 Alberta Street in Riga. Photography by AS Buvuznemums Restaurators. In: Dalia Klajumiene, Pasaulietiniai interjerai: ideja, dekoras, dizainas (Vilnius: VDA, 2013), 195 
practical parts of buildings. According to Klajumienè, tiles were used in places of intensive movement, such as entrance halls, lobbies, porches, lounges, staircases, bathrooms, and toilets. ${ }^{44}$ Ceramic and mettlach tiles are waterproof, temperature resistant, and low maintenance. Because of that, tiles quickly made their way into Lithuanian interior decor and were perfect for utilitarian high-quality use.

There are lots of secession style décor elements in the Gelgaudiškis manor palace. It is disappointing that no iconographic material has been found and it is uncertain what the furniture and other interior elements looked like. However, it was noticed that moldings were created with ornaments of national plants: lilies of the valley, ferns, clovers, and other water and field flowers. Also, an abstract secession design was found in Gelgaudiškis manor house interiors, too. There are hints of similarities to the Tassel House, the Secession of Riga, and others.

\section{PAEŽERIAI (ŠIAULIAI DISTRICT)}

Paežeriai manor house was built around 1910. Fortunately, in this manor residence's case there are some photographs of manor house interior. As mentioned earlier, the floor plan was different in representation area on the ground floor and private rooms on the first one. In the corner of the main hall on the ground floor there is a door to a terrace and a park. In the opinion of Kalsauskaite-Gasparavičienè, after the 1940s, fireplaces of the main salon were demolished and removed to another place. ${ }^{45}$ However, in the photos published by Roman Aftanazy in 1939, the fireplaces were still in their places. It is visible in the photos that the fireplaces were made from white glazed round form title. Acording to Aftanazy, walls of representational halls and rooms had profiled cornices and wallpapers; furniture was made in the late 19th-early 20 th century and was exclusively of the secession style. ${ }^{46}$

The main salon walls were covered in secession style ornamented wallpapers (Fig. 10). Secession style décor is not as common in Lithuanian manor houses as the Baroque, classicism, or any other historical style. Bedrooms or entrance halls were usually decorated in this new style, but, in Paežeriai and Gelgaudiškis' cases, the secession style design is in

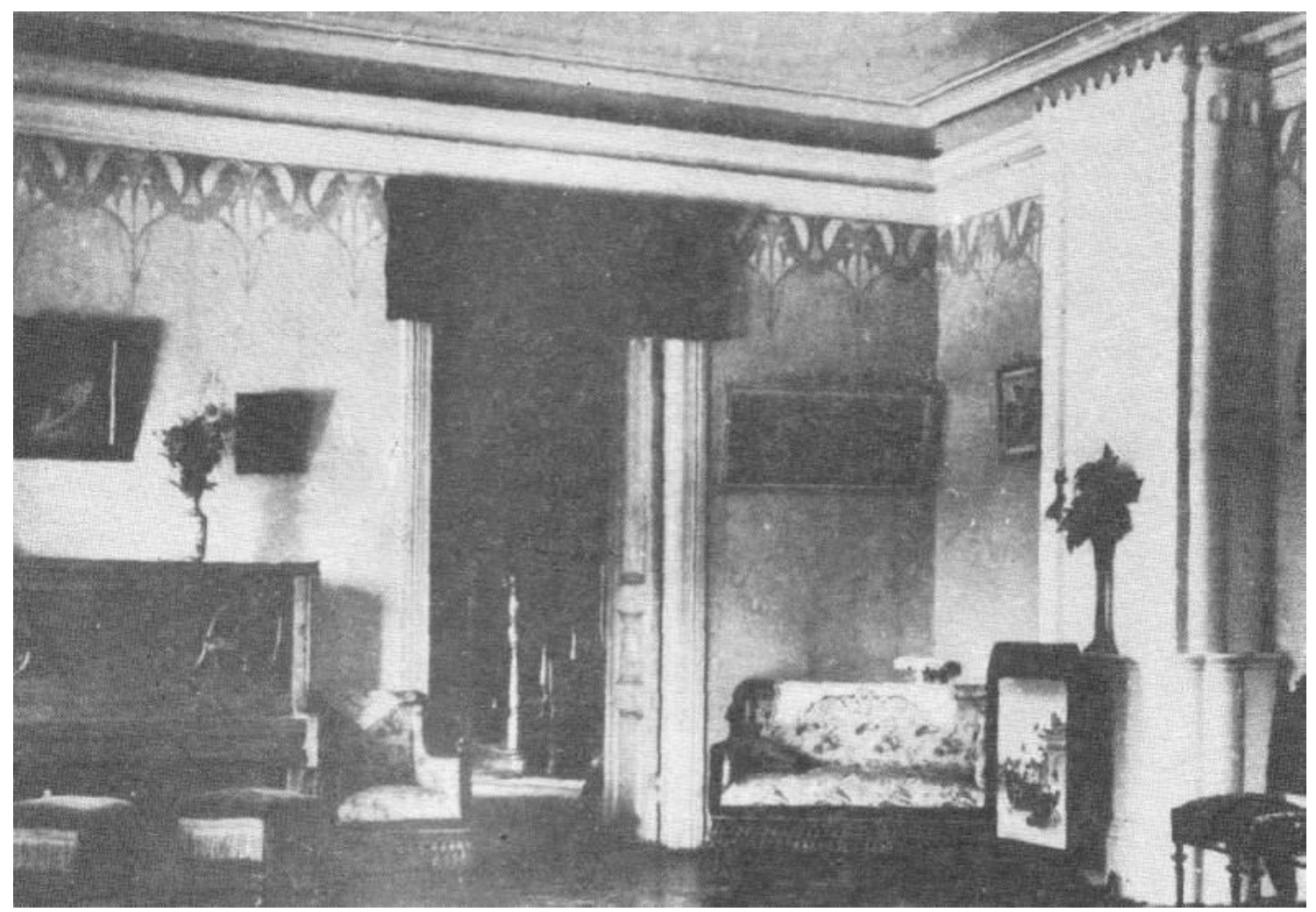

Fig. 10. The main salon of Paežeriai manor house around 1939. In: Roman Aftanazy, Dzieje rezydencji na dawnych kresach Rzeczypospolitej. Wojewodstwo wilenskie. T. 3 (Wrocław: Zakład Narodowy imienia Ossolińskich Wydawnictwo, 1992), 256 
the representational rooms. Also, in this salon, there was curvy shaped secession style furniture with tassels and fringes on the bottom. A piano was an important part of cultural life in Lithuanian manors. In the Paežeriai salon, this musical instrument was placed in the corner, surrounded by secession style pouffes and armchairs. It was probably one of the cosiest places in the building for the family to spend some time together. Besides, in the already mentioned Aftanazy's photos, there is a landscape painting and a mirror next to it. Also, there is a round table with a secession style embroidered tablecloth and a lamp on it. Cushions and small-format photographs created a cosy feeling to this room, as well.

\section{BURBIŠKIS (RADVILIŠKIS DISTRICT)}

The central building of Burbiškis manor was converted from a barn when the wooden former living house burnt down. It was a very interesting and unusual decision. Later on, other buildings were built next to this manor house to create a private yard. Historical sources, inventories, and photographs were found in residence rooms that showed elements of secession style. In the 1913 inventory, the floor plan is described as an enfilade. This document also described interior décor details: the flooring was made of colourful parquet with carpets, the walls had colourful décor and the ceilings were white. The inventory mentions "marble fireplaces", but glazed tiles were had in mind, probably. A lot of furniture was made from dark wood. There were modern appliances, such as two radios and gramophones, as well as the traditional ones, like a grand piano. Various art objects in the interior included family members' busts, sculptures, and paintings. ${ }^{47}$

There were mirrors in almost every room. At that time, this was still a huge luxury. Even in the manor culture, mirrors were not as casual as they are to us today. Mirrors were more like art pieces by themselves, used to create an aesthetic view of a room. According to Indrè Užuotaitè, "mirrors were inseparable from decorativeness and representativeness of interiors of manors, both in the 19th century and the early 20th century, a reflection of a mirror 'multiplied' the artistic value of rooms and the luxurious frames themselves were considered works of art." ${ }^{48}$

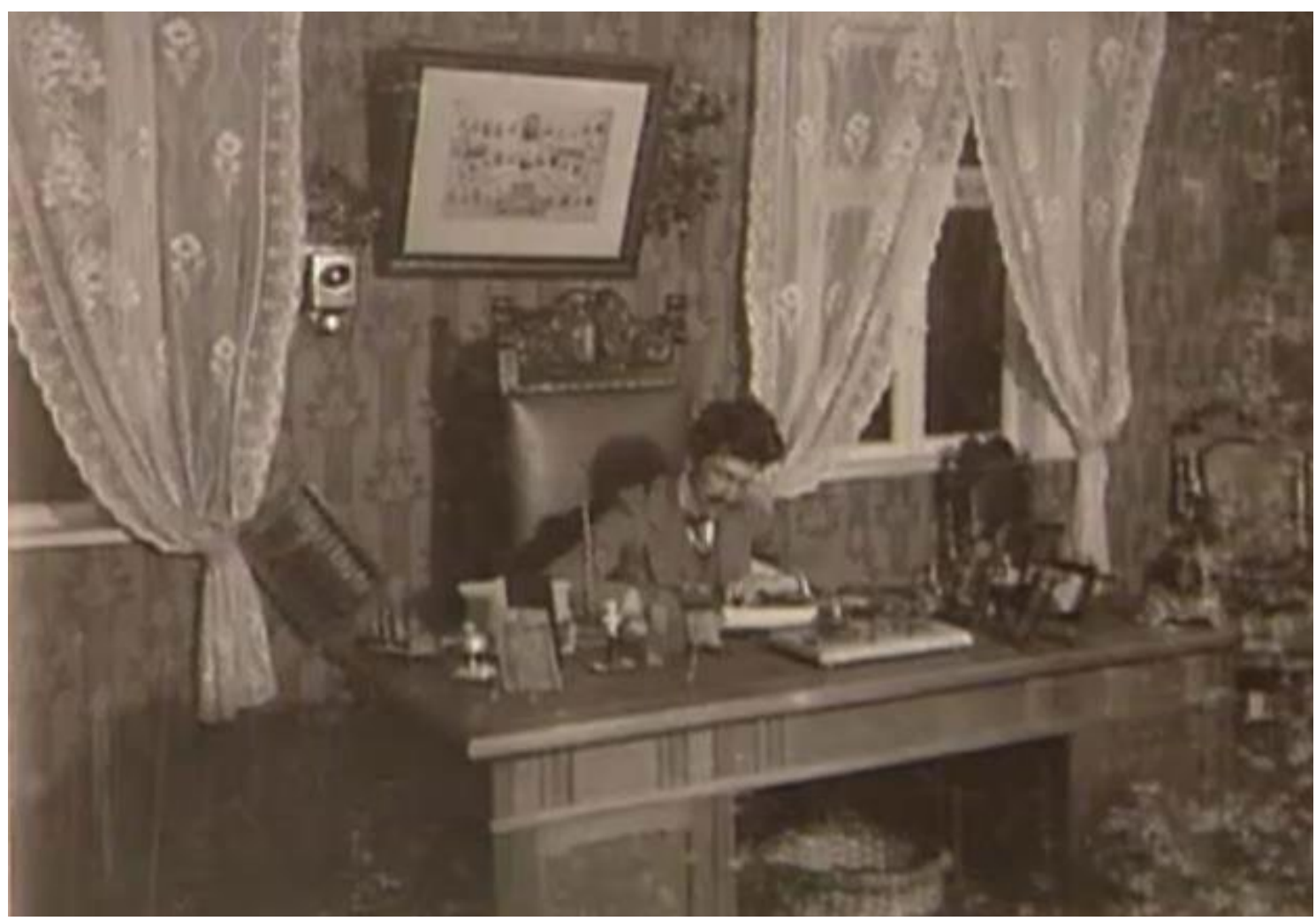

Fig. 11. Office in Burbiškis manor. Late 19th century-early 20th century. Accessed February 12, 2019. https://www.lrt.lt/ mediateka/irasas/8367/vizijos-ir-tikrove-burbiskio-dvaras 
There are several surviving photographs of Burbiškis manor house's interior. From this iconographic information it is known that the office walls were covered with secession style wallpapers (Fig. 11). Other pictures capture secession style furniture and a floor lamp covered with fabric-it was a common interior decoration element in the secession period. Secession style wallpapers and wall decorations, historicist style furniture, and mirrors were found in relative abundance in Burbiškis manor, as well.

\section{ŠEŠUOLĖLIAI (ŠIRVINTAI DISTRICT)}

Current interior of Šešuolèliai manor was restored from remaining authentic elements. This manor house was built or reconstructed in 1900. The date remains on the cellar paving. It could have been an older building's reconstruction, but in this case no further information remains.

Secession style décor starts from the doors of the main entrance. The porch is curvy lines and shaped wooden panels, the same motives can be found in one of the halls, too. Doors of the main entrance are made from glass and ironwork. The restored banister is another interesting example of ironwork. There is also a green glazed fireplace which is still in-tact and is located in the entrance hall. Fireplaces of this colour were popular all over Europe in the secession period; glazed tiles of the same colour were used in the Rokiškis Palace's dining room and Gelgaudiškis manor house's fireplaces.

The hall with wooden panel decorations is considered to be the most valuable (Fig. 12). It has the same motifs as the porch of the first door: fragments of curvy lines on the walls and shutters. The plafond is supported with consoles. There is a glazed green fireplace in this corner of the room, too. More secession style décor is found in private rooms and bedrooms. It is agreed that the Šešuolèliai Palace, both exterior and interior, is a valuable object of Lithuanian architectural heritage. Lukšionytė-Tolvaišienè: “The interior of Šešuoleliai manor is considered to be the earliest décor of the modern style in Lithuania." ${ }^{49}$ According to the manor's cultural heritage document, "it is an object of cultural value, the residence is from historicism and the period of secession, the most valuable example of the secession style mansion architecture in Lithuania." 50

\section{CONCLUSIONS}

To sum it up, secession first of all affected perspectives on floor planning and adaptation of space to individual desires in Lithuania. Introduction of water supply, sewerage, central heating, and electricity changed the everyday life completely. Organic, modern elements enlivened interior décor. Although the secession was less expressive in Lithuania than in other countries, it can be stated that secession style influenced Lithuania even in the Tsarist period.

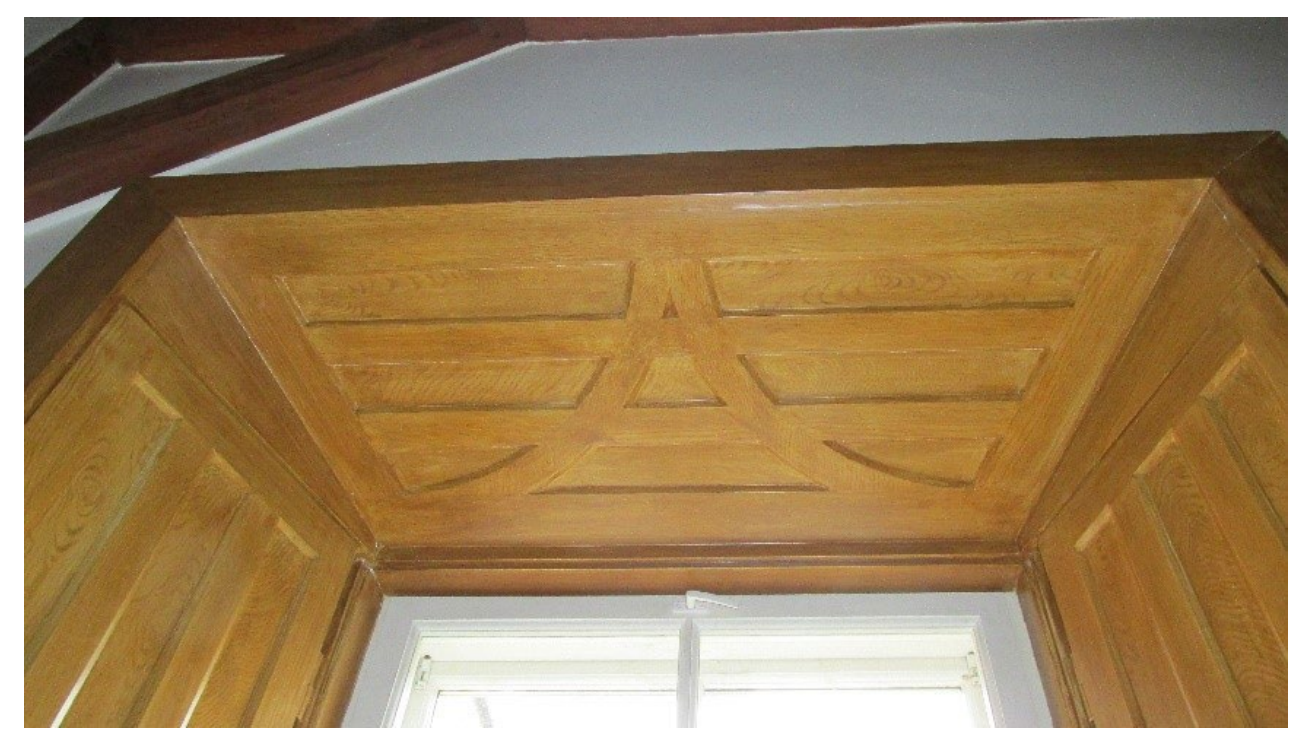

Fig. 12. Fragments of curvy lines on walls and shutters in Šešuoleliai manor house. Photography by Rimantè Stankūnaitè, 2018 
Newly built or reconstructed manor residences in Paežeriai, Burbiškis, and Šešuolèliai are characterised by asymmetrical compositions, volume and height division, and diverse décor. Changes in floor planning affected construction of buildings. Secession's cultural movement influenced human desire for private spaces and adaptation of houses to their needs and not to balls or other big meetings. Newly customised entrance hall's place changed the whole building's floor planning. Despite that, enfilades were used in representational halls, whereas private spaces had corridors, as seen in Gelgaudiškis, Šešuolèliai, and Paežeriai manor houses.

Only two rooms of the Renavas palace were decorated in secession style - in the entrance hall secession style décor was created with combination of organic plant motives and abstract elements. Renavas secession interior design was created from ornaments from European secession aesthetics in combination with Lithuania’s local details.

In Gelgaudiškis palace, the majority of rooms are decorated in secession style. Secession style moldings can be seen on friezes, cornices, and ceilings; door décor relates to that of the rest of the room. This manor house's interior is created by combining abstract and natural elements of secession.

Polychromic researches on Gelgaudiškis, Renavas, and Šešuoleliai manor residences make it clear that the décor colours were of secession style. The same colours were used all over Europe: light, pastel green and blue.

The style of the Zakopane region created a different perception of secession. Zakopanski style interior was created in Rokiškis and Šešuolèliai residences. Wooden décor of walls and ceilings was the main aspect in the early 20th century's secession interior.

Photographs of Burbiškis and Paežeriai residences show the kind of furniture that was used. Iconographic sources show that eclecticism was acceptable. Secession style embroidered fabrics and cushions were used.

Inventories, memoirs, photographs, polychromic and historical researches make it clear that secession style was popular in Lithuanian manor residences, but not many examples have survived to this day.

\section{References}

Aftanazy, Roman. Dzieje rezydencji na dawnych kresach Rzeczypospolitej. Wojewodstwo wilenskie. Vol. 3. Wrocław: Zakład Narodowy imienia Ossolińskich Wydawnictwo, 1992.

Andrijonas, Antanas, Korzonaite, Edita, and Vaitkus, Vytautas eds. Gelgaudiškis. Vilnius: Versmè, 2011.

Burbiškio dvaro sodybos istorine medžiaga. Daugyvenès kultūros istorijos muziejaus - draustinio archyvas. F. RPT, ap. 12, b. 71, 2007.

Cieškaitè-Brèdikienė, Laimutè. Dizaino raida. Nuo Morriso iki Morrisono. Vilnius: VDA, 2008.

Dailès žodynas. Vilnius: Vilniaus dailès akademijos leidykla, 1999.

Daujotaitė, Irena. Buv. Renavo dvaras. Interjero dekoro fragmenty spalvines kopijos. Patalpos 1, 4. VAA, F. 1019, ap. 11, b. 3717, 1986.

Glemža, Jonas Rimantas. Istoriniai Lietuvos architektūros paveldo interjerai: istorija, tvarkyba, vertinimas. Vilnius: VDA, 2013.

Harris, Cyril M. Dictionary of Architecture and Construction. London: The McGraw-Hill Company, 2006.

Kalasauskaitė-Gasparavičienė, Sigita. Paežerių buv. dvaro sodybos paminklosauginiu sąlygų dokumentacija. Historical Certificate. VAA. F. 1019, ap. 11, b. 14190, 1992.

Klajumiené, Dalia. Vilniaus gyvenamuju namu interjery dekoro elementai nuo klasicizmo iki moderno. Vilnius: VDA, 2015.

Kutkaitytė, Monika. Dvaru restauravimo tendencijos ir klaidos. ASA.lt, September 1, 2008. http://lt.lt.allconstructions.com/portal/index/article/5128/dvaru-restauravimo-tendencijos-ir-klaidos.

Laurinaitienè, Dalia. Buv. Gelgaudiškio I a. patalpu ankstyvuju dažymu etapu schema ir patalpu dažymo projektai. Kaunas: $\mathrm{AB}$ "Kauno paminklų restauravimo projektavimo institutas", 2012.

Lukšionytė-Tolvaišienè, Nijolè. Lietuvos architektūros istorija. Nuo XIX a. II-ojo dešimtmečio iki $1918 \mathrm{~m}$. Vilnius: Savastis, 2000.

Lukšionytė-Tolvaišienè, Nijolè. "Renavo dvaro ansamblio meninès ypatybès." In Renavas, Žemaičiu praeitis, edited by Adomas Butrimas, Asta Miltenytè, and Povilas Šveberas. Vilnius: VDA, 2012. 75-90.

Lukšionytė-Tolvaišienè, Nijolè. Istorizmas ir modernas Vilniaus architektūroje. Vilnius: Vilniaus dailès akademijos leidykla, 2000.

Lukšionytè-Tolvaišienė, Nijolè. Gubernijos laikotarpis Kauno architektūroje. Kaunas: Vytauto Didžiojo universiteto leidykla, 2001.

Preišegalavičiené, Lina. Lietuvos tarpukario interjerai 1918-1940. Kaunas: Vox Altera, 2016.

Rokiškis, Tyzenhauzu al. Nr. 5. Buvę Rokiškio centriniai dvaro rūmai. Žvalgybiniai polichrominiai interjero tyrimai. Report. VAA. F. 1019, ap. 11, b. 3740, 1991.

Šešuolèliu dvaro pagrindinis dosjë. Kultūros paveldo centras, 2004.

Tarabildienè, Romualda. Buv. Renavo dvaras. Centriniai rūmai. TDP. AS dalis. VAA, F2, 283-55, 1988.

Trečiokienè, Verutè. Buv. Gelgaudiškio dvaro I a. patalpu ankstyvuju dažymu etapu schema ir patalpu dažymo projektai. 2009. Accessed May 3, 2018. https://kvr. $\mathrm{kpd} . \mathrm{lt} / \# /$ static-heritage-detail/4f61fb7e-b43b-43ca-b 9d6-78a1c8c0579a. 
Užuotaitė, Indrè. "Modernèjanti Lietuvos visuomenè ir veidrodžiai interjeruose: nuo prabangos iki būtinybès." In Pasaulietiniai interjerai: ideja, dekoras, dizainas, edited by Dalia Klajumienè. Vilnius: Vilniaus dailès akademijos leidykla, 2014. 157-174.

\section{Notes}

1 Nijolè Lukšionytė-Tolvaišienè, Lietuvos architektūros istorija. Nuo XIX a. II-ojo dešimtmečio iki $1918 \mathrm{~m}$. (Vilnius: Savastis, 2000), 411.

2 Ibid.

3 Ibid., 342-398.

4 Nijolè Lukšionytė-Tolvaišienè, Istorizmas ir modernas Vilniaus architektūroje (Vilnius: Vilniaus dailès akademijos leidykla, 2000); Nijolè Lukšionytė-Tolvaišienè, Gubernijos laikotarpis Kauno architektūroje (Kaunas: Vytauto Didžiojo universiteto leidykla, 2001).

5 Dalia Klajumienè. Vilniaus gyvenamuju namy interjery dekoro elementai nuo klasicizmo iki moderno (Vilnius: VDA, 2015).

6 Ibid., 704.

7 Laimutė Cieškaitè-Brèdikienè, Dizaino raida. Nuo Morriso iki Morrisono (Vilnius: VDA, 2008).

8 Burbiškio dvaro sodybos istorine medžiaga (Daugyvenès kultūros istorijos muziejaus - draustinio archyvas. F. RPT, ap. 12, b. 71).

9 Kalsauskaitè-Gasparavičienè, Paežeriu buv. dvaro sodybos paminklosauginiu salygu dokumentacija. Historical Certificate (VAA. F. 1019, ap. 11, b. 14190).

10 Daujotaite, Buv. Renavo dvaras. Interjero dekoro fragmentu spalvines kopijos. Patalpos 1,4 (VAA, F. 1019, ap. 11, b. 3717, 1986); Tarabildienè, Buv. Renavo dvaras. Centriniai rūmai. TDP. AS dalis (VAA, F. 2, 283-55, 1988).

11 Rokiškis, Tyzenhauzu al. Nr. 5. Buve Rokiškio centriniai dvaro rūmai. Žvalgybiniai polichrominiai interjero tyrimai. Report (VAA. F. 1019, ap. 11, b. 3740, 1991).

12 Šešuolèliu dvaro pagrindinis dosjë (Kultūros paveldo centras, 2000-2004).

13 Trečiokienè, Buv. Gelgaudiškio dvaro I a. patalpu ankstyvuju dažymu etapu schema ir patalpu dažymo projektai, 2009. Accessed May 3, 2018. https://kvr.kpd. lt/\#/static-heritage-detail/4f61fb7e-b43b-43ca-b9d678a1c8c0579a. Laurinaitienè, Buv. Gelgaudiškio I a. patalpu ankstyvuju dažymu etapu schema ir patalpy dažymo projektai (Kaunas: AB "Kauno paminklu restauravimo projektavimo institutas," 2012).

14 Kultūros vertybiu registras. Accessed December 8, 2018. https://kvr.kpd.lt/\#/static-heritage-search.

15 Klajumienè, 16.

16 Dailès žodynas (Vilnius: Vilniaus dailès akademijos leidykla, 1999), 108.

17 Cyril M. Harris, Dictionary of Architecture and Construction (London: The McGraw-Hill Company, 2006), 615.
18 Ibid.

19 Ibid., 200.

20 Lukšionytė-Tolvaišienè, Lietuvos architektūros istorija, 50-51.

21 Ibid., 342-377.

22 Ibid., 409.

23 Preišegalavičienė, Lietuvos tarpukario interjerai 19181940 (Kaunas: Vox Altera, 2016), 207.

24 Lukšionytè-Tolvaišienè, Lietuvos architektūros istorija, 409 .

25 Ibid.

26 Nijolè Lukšionytè-Tolvaišienè, "Renavo dvaro meninès ypatybès" in Renavas, Žemaičiu praeitis, ed. A. Butrimas, A. Miltenytė, and P. Šveberas (Vilnius: VDA, 2012), 84.

27 Lukšionytè-Tolvaišienè, Lietuvos architektūros istorija, 434.

28 Trečiokienè, 21.

29 Lukšionytè-Tolvaišienè, Lietuvos architektūros istorija, 434.

30 Jonas Rimantas Glemža, Istoriniai Lietuvos architektūros paveldo interjerai: istorija, tvarkyba, vertinimas (Vilnius: VDA, 2013), 497.

31 Lukšionytė-Tolvaišienè, "Renavo dvaro meninès ypatybès," 84.

32 Ibid., 86.

33 Daujotaite; Tarabildiené.

34 Lukšionytè-Tolvaišienè, "Renavo dvaro meninès ypatybės," 85.

35 Ibid.

36 Ibid., 79.

37 Glemža, 493-496.

38 Daujotaitè.

39 Rokiškis, Tyzenhauzų al. Nr. 5.

40 Glemža, 497.

41 Trečiokienè, 4

42 Gelgaudiškis, ed. A. Andrijonas, E. Korzonaite, V. Vaitkus (Vilnius: Versmè, 2011), 226-227.

43 Trečiokiene், 8.

44 Klajumienè, 590.

45 Kalsauskaitè-Gasparavičienè.

46 Roman Aftanazy, Dzieje rezydencji na dawnych kresach Rzeczypospolitej. Wojewodstwo wilenskie. Vol. 3. (Wrocław: Zakład Narodowy imienia Ossolińskich Wydawnictwo, 1992), 256-257.

47 Burbiškio dvaro sodybos istorinè medžiaga.

48 Užuotaitè, "Modernèjanti Lietuvos visuomenè ir veidrodžiai interjeruose: nuo prabangos iki bütinybès" in Pasaulietiniai interjerai: ideja, dekoras, dizainas, ed. Dalia Klajumienè (Vilnius: Vilniaus dailès akademijos leidykla, 2014), 172.

49 Lukšionytè-Tolvaišienè, Lietuvos architektūros istorija, $442-443$.

50 Šě̌uolèlių dvaro pagrindinis dosjè. 
Rimanté BARATINSKIENE

Vytauto Didžiojo universitetas, Kaunas, Lietuva

\section{SECESIJOS DEKORO ELEMENTŲ PAPLITIMAS LIETUVOS DVARŲ REZIDENCIJŲ INTERJERUOSE}

Santrauka

Šiame straipsnyje norime pristatyti secesijos stilistikos įtaką Lietuvos dvarų rezidencijų interjerui. Kitokia nei istoristiniai stiliai ir tuo unikali secesija plito labai neilgai, todèl ne visose Europos šalyse spejo išpopuliarèti. Šis organiškas stilius dažnai tapatinamas su miesto kultūra, tačiau verta pastebėti, kad anksčiau kultūrinis gyvenimas Lietuvoje virè dvarų aplinkoje. Visgi secesijos dekoras ir interjeras nèra toks dažnas reiškinys dvarų rezidencijose kaip miestų pastatuose. Būtent todèl kiekviena randama išlikusi secesijos detalè yra naudinga ir svarbi Lietuvos architektūros paveldui. Remiantis keliais pavydžiais: Renavo, Rokiškio, Gelgaudiškio, Paežerių, Burbiškio ir Šešuolèlių dvarų reprezentacinių pastatų interjerais, išryškẻja secesijos stilistikos požymiai Lietuvos užmiesčio rezidencijose. Naujojo stiliaus plitimo metu eksterjere ịsivyravo asimetrija, keitėsi pastato išplanavimas ir privačios erdvės suvokimas, paplito nauja interjero puošybos stilistika. Ikonografijos išlikę nedaug, todèl, remiantis istoriniais, menotyriniais ir polichrominiais tyrimais, galima sujungti turimą informaciją ir aprašyti pasireiškusias secesijos stilistikos detales Lietuvos dvarų rūmų interjere.

Reikšminiai žodžiai: secesijos interjeras, Lietuvos dvarų rezidencijų interjeras, secesija dvaruose.

Gauta 2019-02-12

Parengta spaudai 2019-06-03

Rimantė BARATINSKIENÉ

MA in Faculty of Arts of Vytautas Magnus University, Kaunas, Lithuania.

Her research interest is the history of Lithuanian manors' interior design. 